\title{
Democracy or Plutocracy? America's Existential Question
}

\begin{abstract}
Americans are proud of their democratic political system. But the facts show that America has increasingly come to resemble a plutocracy, where society is governed "of the $1 \%$, by the $1 \%$, for the $1 \%$ ".
\end{abstract}

Is the United States of America still a functioning democracy or has it become, for all practical purposes, a plutocracy? And why is this question important? It's important because the answer to the question of whether America has a dark or shining future will depend on whether it's a democracy or plutocracy. Indeed, this question may well be the most existential question America has to address.

\section{The Difference Between "Democracy" and "Plutocracy"}

Let's begin to answer this question from the very beginning. What is the actual difference between a democracy and a plutocracy? In a democracy, the masses broadly determine their future. Equally critically, in terms of the economy, society, and political system there is a level playing field where the working classes, middle classes, and affluent elites compete. The term "level playing field" is absolutely critical here. Many Americans believe that their economic and political systems create a level playing field in which the poor and disadvantaged can rise to the top. This is also why there is no social resentment of billionaires in America. Most Americans believe that they have an equal opportunity to become billionaires. So the first big question we need to address is this: is there a level playing field for the poor and rich?

The honest answer is no. Today, when working class or even middle-class Americans have to compete with the affluent elites, they are not competing on a level playing field. They have to run uphill to score goals. By contrast, the affluent elites run downhill as the playing field is tilted in their favor. Writing in the Financial Times in June 2019, Edward Luce provides one statistic to drive home this point: "Studies show that an eighth grade [i.e., a 14-year-old] child from a lower income bracket

Originally published in Horizons, Autumn, 2020 
who achieves maths results in the top quarter is less likely to graduate than a kid in the upper income bracket scored in the bottom quarter. This is the reverse of how meritocracy should work."

There is no shortage of data to drive home the point that there is no longer a level playing field in America. Anand Giridharadas, a former New York Times columnist, has documented in great detail in his book Winners Take All (2018) how the dream of the American middle class has effectively evaporated. As he says:

A successful society is a progress machine. It takes in the raw material of innovations and produces broad human advancement. America's machine is broken. When the fruits of change have fallen on the United States in recent decades, the very fortunate have basketed almost all of them. For instance, the average pretax income of the top tenth of Americans has doubled since 1980, that of the top $1 \%$ has more than tripled, and that of the top $0.001 \%$ has risen more than sevenfold - even as the average pretax income of the bottom half of Americans has stayed almost precisely the same. These familiar figures amount to three and a half decades' worth of wondrous, head-spinning change with zero impact on the average pay of 117 million Americans.

Giridharadas claims that the American people are beginning to "feel" that the system is unfair:

Thus many millions of Americans, on the left and right, feel one thing in common: that the game is rigged against people like them. [...] There is a spreading recognition, on both sides of the ideological divide, that the system is broken, that the system has to change.

Giridharadas is right. To create a level playing field, the system has to change. But it will not change. Why not? What are the obstacles to change? And, if there are obstacles, why hasn't the world's freest media, the American media, revealed these obstacles? This is where the story becomes complex. We also have to venture into politically controversial territory to understand the obstacles to change.

\section{Main Obstacle to Change}

The main obstacle to change is a myth. An example from history will help. For centuries, European serfs accepted a feudal system in which they were second-class citizens (if not slaves) in a system dominated by feudal lords. Why didn't the majority of serfs overthrow the minority of feudal lords? A huge myth was created to generate a belief that this system was just. The kind and gentle feudal lords reinforced the myth. At the risk of quoting a politically controversial philosophical concept, let me mention a term used for this phenomenon: false consciousness. According to Daniel Little, Chancellor Emeritus and Professor of Philosophy at University of MichiganDearborn, "false consciousness" is a concept derived from Marxist theory of social class. [...] Members of a subordinate class (workers, peasants, serfs) suffer from false consciousness in that their mental representations of the social relations around them systematically conceal or obscure the realities of subordination, exploitation, and domination of those relations embody. Marx asserts that social mechanisms 


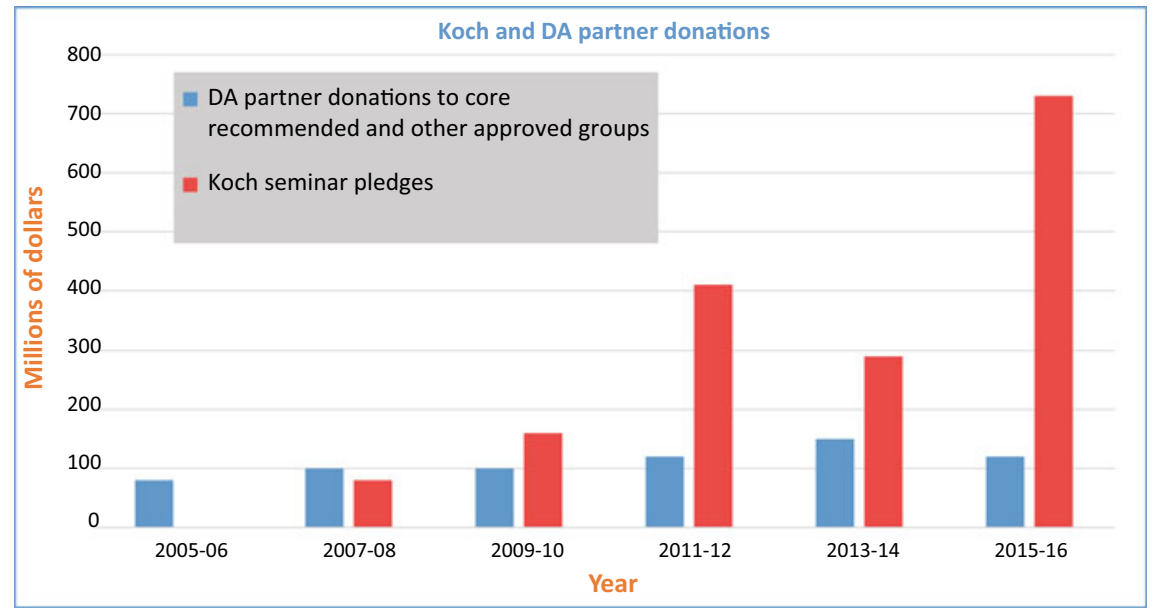

Fig. 1 Democracy Alliance Figures and Koch and DA Partner Donations Source Democracy Alliance figures from LeMarche 2014, supplement with correspondence from the Democracy Alliance. Koch seminar figures from media reports of seminars

emerge in class society that systematically creates distortions, errors, and blind spots in the consciousness of the underclass. If these consciousness-shaping mechanisms did not exist, then the underclass, always a majority, would quickly overthrow the system of their domination (Fig. 1).

Yet, even if contemporary Americans were to accept that there was "false consciousness" in the feudal era, they would contest the possibility of it emerging in modern American society, where the unique combination of the world's freest and fiercely independent media, the best universities, the best-funded think tanks and the spirit of open and critical inquiry would expose any big "myth" that enveloped American society. Many Americans would assert no myths can survive in the robustly open environment of American society. Only facts survive.

To be fair, many American writers have written about the several dimensions of plutocracy in American society. In addition to Giridharadas, who was cited earlier, distinguished American writers like Nobel Laureate Joseph Stiglitz and Robert Reich have documented, for example, the growing inequality in America. In his brilliant May 2011 Vanity Fair article entitled, "Of the 1\%, by the 1\%, for the 1\%," Stiglitz opines that it's no use pretending that what has obviously happened has not in fact happened. The upper $1 \%$ of Americans are now taking in nearly a quarter of the nation's income every year. In terms of wealth rather than income, the top $1 \%$ control $40 \%$. Their lot in life has improved considerably. Twenty-five years ago, the corresponding figures were $12 \%$ and $33 \%$.

Yet what most of these articles emphasize is the growing "inequality" in America. And if the problem is "inequality," then fortunately the problem can be solved. As America has the world's most robust democratic system, where the broad masses elect the leaders who in turn take care of the interests of the broad masses, any problem 
of "inequality" could eventually be fixed. In short, if America has a problem, it also has a solution: democracy.

This brings us to the heart of the argument of this essay. To put it simply, the solution has become part of the problem. While all the democratic processes remain in place, with Americans going to the polls every two or four years (depending on the elected office) to select their leaders (who will, in theory, take care of them), the results of all those processes are that Americans elect leaders who will take care of the $1 \%$, not the $99 \%$.

How did this happen? How did America, which on the surface still functions as a democracy, become a plutocracy, which takes care of the interest of the 1\%? [Note: the term 1\% is used metaphorically here. The real reference is to a tiny elite that benefits from a non-level playing field].

There was one great American who anticipated the effective hijacking of the American democratic system by the very affluent. He is America's greatest political philosopher of recent times, John Rawls. Rawls warned that "if those who have greater private means are permitted to use their advantages to control the course of public debate," this would be the corrupting result:

Eventually, these inequalities will enable those better situated to exercise a larger influence over the development of legislation. In due time they are likely to acquire a preponderant weight in settling social questions, at least in regard to those matters upon which they normally agree, which is to say in regard to those things that support their favored circumstances.

This is precisely what has happened over the past few decades: the affluent have gained "preponderant weight $[\ldots]$ in regard of those things that support their favored circumstances." There has been a relative transfer of wealth and political power from the vast majority of America's population to a privileged super minority.

The practical effect of transferring power to a super minority is that the political system responds to the needs and interests of the top 1\%, not to the $99 \%$. Fortunately, there have been strong, peer-reviewed academic studies that confirm this political reality. Two Princeton University professors have documented how ordinary American citizens have lost their political power and influence. Martin Gilens and Benjamin Page studied the relative influence that the views of average Americans and mass-based interest groups have on policy outcomes versus the views of the economic elite in 1,779 cases. They found that: "economic elites and organized groups representing business interests have substantial independent impacts on US government policy, while average citizens and mass-based interest groups have little or no independent influence. [...] When the preferences of economic elites and the stands of organized interest groups are controlled for, the preferences of the average American appear to have only a minuscule, near-zero, statistically non-significant impact upon public policy. [...] Furthermore, the preferences of economic elites (as measured by our proxy, the preferences of "affluent" citizens) have a far more independent impact upon policy change than the preferences of average citizens do. [...] In the United States, our findings indicate, the majority does not rule-at least not in the causal sense of actually determining policy outcomes." 
They reach the following alarming conclusion: "Americans do enjoy many features central to democratic governance, such as regular elections, freedom of speech and association, and a widespread (if still contested) franchise. But we believe that if policymaking is dominated by powerful business organizations and a small number of affluent Americans, then America's claims to being a democratic society are seriously threatened."

In the past, the broad middle classes of America had a strong say in determining the fundamental direction of American society. Today, they no longer do. The decisions of the US Congress are not determined by the voters; they are determined by the funders. As a result, America is becoming functionally less and less of a democracy, where all citizens have an equal voice. Instead, it looks more and more like a plutocracy, where a few rich people are disproportionately powerful.

These conclusions have been reinforced by other academic studies. A 2018 study by scholars Alexander Hertel-Fernandez, Theda Skocpol, and Jason Sclar of the School of International and Public Affairs at Columbia University further argued that since the mid-2000s, newly formed conservative and progressive donor consortiaabove all the Koch seminars [founded by brothers Charles and David Koch] and the DA [Democracy Alliance]-have magnified the impact of wealthy donors by raising and channeling ever more money not just into elections but also into full arrays of cooperating political organizations. [...] The Koch seminars [...] allowed donations to be channeled into building a virtual third political party organized around AFP [Americans for Prosperity], an overarching political network able not only to electorally support the Republican Party but also to push and pull its candidates and office holders in preferred ultra-free-market policy directions. [...] To the degree that wealthy donor consortia have succeeded in building organizational infrastructures, they have shifted the resources available for developing policy proposals, pressing demands on lawmakers, and mobilizing ordinary Americans into politics. [...] When plutocratic collectives impose new agendas on political organizations seeking to attract financial resources, the funders reshape routines, goals, and centers of power in US politics well beyond the budgetary impact of particular grants. This has resulted in hundreds of millions of dollars that wealthy donors have raised annually within the donor consortia to finance their political interests.

The authors thus conclude: "Our analysis of the Koch and DA consortia highlights that a great deal of big-money influence flows through mechanisms other than individual or business donations to the electoral and lobbying operations. [...] To understand how the wealthy are reshaping US politics, we need to look not just at their election and lobbying expenditures but also at their concerted investments in many kinds of political organizations operating across a variety of fields and functions. Only in this way can we account for the stark inequalities in government responsiveness documented by [various] researchers."

So what triggered this massive transfer of political power from the broad masses to a tiny elite in America? This question will be hotly debated by political scientists and historians for decades. Yet it is also clear that one seminal ruling by the US Supreme Court made a huge difference. In a landmark ruling in Citizens United v. Federal 
Election Commission (2010) as well as in other decisions, many of the legislative restraints on the use of money to influence the political process were overturned.

A report by the Center for Public Integrity reported that: "The Citizens United ruling, released in January 2010, tossed out the corporate and union ban on making independent expenditures and financing electioneering communications. It gave corporations and unions the green light to spend unlimited sums on ads and other political tools, calling for the election or defeat of individual candidates." The impact of this and other Supreme Court decisions was monumental. Effectively, they ended up transforming the American political system. Martin Wolf says that "the Supreme Court's perverse 2010 Citizens United decision held that companies are persons and money is speech. That has proved a big step on the journey of the US toward becoming a plutocracy."

Now, Martin Wolf is one of the most influential columnists in the world. He also describes himself as being fiercely pro-American. In a column written in 2018 , Wolf said "the US was not just any great power. It embodied the causes of democracy, freedom, and the rule of law. This made [my father] fiercely pro-American. I inherited this attitude." America is an open society. Therefore, when major voices like Martin Wolf and Joseph Stiglitz describe America as having become a "plutocracy," the logical result should have been a major public debate on whether this claim is true.

Instead, the opposite happened. This comment by Martin Wolf was buried. The psychological resistance in America to use the term "plutocracy" is deep. Leading newspapers like the New York Times and Washington Post do not use it. Leading columnists like Richard Cohen and Paul Krugman do not use it. Nor do distinguished historians like Simon Schama mention plutocracy. Certainly, no American politician uses it.

So, what is in a name? Shakespeare once famously said, "a rose by any other name would smell as sweet." I sometimes doubt this piece of wisdom. If someone were to change the name of "rose" to "skunk-flower," we might approach a rose with some caution. Choosing the right name makes a huge difference. As the philosopher Ludwig Wittgenstein said, "the limits of my language mean the limits of my world."

The sad reality about the US is that, functionally, there is absolutely no doubt that the political system has gone from functioning as a democracy (a government of the people, by the people, for the people) toward becoming a plutocracy (a government of the $1 \%$, by the $1 \%$, for the $1 \%$ ). Yet, while this political reality is undeniable, it is also unspeakable.

\section{Just and Unjust Inequality}

What is the real danger that flows from this refusal to describe the American political system as a "plutocracy"? Many dangers! Firstly, it perpetuates the myth that American society has a "level playing field." Anybody can succeed. Hence, if a person fails it is because of his individual defects. It is not because the social environment is rigged against the person. Secondly, by refusing to describe it as a plutocracy, the 
fundamental difference between "just inequality" and "unjust inequality" falls to the surface.

The term "just inequality" may seem to be an oxymoron. Yet, it was John Rawls who highlighted this difference. It was he who said that inequality was not the problem. The fundamental question was whether rising inequality resulted in an improvement or deterioration of the living conditions of the people living at the bottom. He states this clearly and categorically: "the higher expectations of those better situated are just if and only if they work as part of a scheme which improves the expectations of the least advantaged members of society."

The best way to illustrate the difference between "just equality" and "unjust equality" is to compare concrete examples. Both the United States and China have about the same level of inequality. By the latest estimates, the gini coefficient in America is 0.41 and in China is 0.39. There is no significant difference here. However, there is a significant difference between how the bottom 50\% have fared in America and China. America is the only major developed society where the average income of the bottom $50 \%$ has declined over a 30 year period from 1980 to 2010, as documented by my colleague of the National University of Singapore, Professor Danny Quah. By contrast, the bottom $50 \%$ of the Chinese population has seen the greatest improvements in their standard of living in recent decades. Indeed, the past 40 years of social and economic development that the Chinese people have enjoyed have been the best 40 years in four thousand years of Chinese history.

The story here is not just about economic failures and economic successes. These economic failures and successes have profound effects on the state of psychological and social well-being of societies. In America, this stagnation of income has also resulted in a lot of human pain and suffering, as documented by two Princeton University economists, Anne Case and Angus Deaton. The white working classes of America used to carry the American dream of getting a better life in their hearts and souls. Today, as Case says, there is a "sea of despair" among them. She and Deaton conclude: "Ultimately, we see our story as about the collapse of the white, high-school-educated working class after its heyday in the early 1970s, and the pathologies that accompany that decline." The detailed study of Case and Deaton documents how poor economic prospects "compounds over time through family dysfunction, social isolation, addiction, obesity, and other pathologies."

In China, the situation is almost exactly the opposite. A Chinese-American psychology research from Stanford University, Jean Fan, visited China in 2019. She observed that "China is changing in a deep and visceral way, and it is changing fast, in a way that is almost incomprehensible without seeing it in person. In contrast to America's stagnation, China's culture, self-concept, and morale are being transformed at a rapid pace-mostly for the better."

One obvious counter-argument to the different social conditions of America and China is that the American people are still better off because they enjoy freedom while the Chinese people do not. It is true that the American people enjoy political freedom. This is undeniable. However, it is also true that a person from the bottom $50 \%$ of American society is more likely to lose their personal freedom and end up in jail. The chance of being incarcerated in America (if one is born in the bottom 
$10 \%$, especially among the black population) is at least five times higher than China. America sends $0.655 \%$ (or 2.12 million) into jails. By contrast, China sends $0.118 \%$ (or 1.65 million) into jails. A 2019 study tried to understand which ethnic group in America had the greatest percentage of individuals with family members in jail or prison. The average figure for all Americans was $45 \%$. The figure for whites was $42 \%$, Hispanics $48 \%$, and blacks $63 \%$.

Any American who has doubts about the dangers posed by plutocracy should pause and reflect on these figures. Let's repeat the figure: $45 \%$ of Americans have family members in jail or prison. These high levels of incarceration did not happen because the American people have psychological characteristics that make them more likely to become criminals. This is a result of the socio-economic conditions of the bottom $50 \%$ that have steadily deteriorated.

If it is manifestly obvious that the American political system is facing a crisis, why is there no consensus on the American body politic on what has gone wrong? Surely the best newspapers and universities, and the best-known students and professors in the world, should be able to arrive at a clear consensus on the real problems faced by American society?

In the year 2020, we can understand why there was no consensus. The liberal elites were distracted by one major issue: the possible reelection of Donald Trump. They believe that it would be a disaster if Donald Trump is reelected. They also believe that many of America's problems would be solved if Joe Biden wins. I share the hope that Biden will win. Yet, even if he wins, the systemic issues that led to the development of a plutocracy in America will not go away. Money will still dominate the political system.

If anyone doubts this, the following data from an important 2018 study written by Thomas Piketty, Emmanuel Saez, and Gabriel Zucman that appeared in the Quarterly Journal of Economics confirms this very clearly: First, our data show a sharp divergence in the growth experienced by the bottom $50 \%$ versus the rest of the economy. The average pretax income of the bottom $50 \%$ of adults has stagnated at about USD 16,000 per adult (in constant 2014 dollars, using the national income deflator) since 1980, while average national income per adult has grown by $60 \%$ to USD 64,500 in 2014. As a result, the bottom $50 \%$ income share has collapsed from about $20 \%$ in 1980 to $12 \%$ in 2014 . In the meantime, the average pretax income of top $1 \%$ adults rose from USD 420,000 to about USD 1.3 million, and their income share increased from about $12 \%$ in the early 1980 s to $20 \%$ in 2014 . The two groups have essentially switched their income shares, with eight points of national income transferred from the bottom $50 \%$ to the top $1 \%$. The top $1 \%$ income share is now almost twice as large as the bottom $50 \%$ share, a group that is by definition 50 times more numerous. In 1980 , top $1 \%$ adults earned on average 27 times more than bottom $50 \%$ adults before tax, while they earn 81 times more today.

There are two ways of viewing this great divergence. It could be a result of the fact that the top $1 \%$ of Americans are becoming smarter and the bottom 50\% of Americans are becoming less smart. Or it could be a result of the fact that America has become a plutocracy where there is no longer a level playing field. All the evidence points 
to the latter conclusion. Many Americans sense that the system does not work for them.

Deteriorating socio-economic conditions mean that people will suffer. All this is brought out by the latest Social Progress Index which was released in September 2020. Quite astonishingly, out of 163 countries assessed worldwide, America, Brazil, and Hungary are the only three countries where people have become worse off. The index collects several metrics of well-being, including nutrition, safety, freedom, the environment, health, education, and others to measure the quality of life in a country. America slipped from number 19 to number 28 in the world. Writing with reference to the aforementioned results, New York Times columnist Nicholas Kristof corroborates deteriorating quality of life with "rising distress and despair." Quite shockingly, Kristof describes how one-quarter of the children with whom he went to school on the same school bus is now dead from drugs, alcohol, and suicide. His personal experience mirrors what Case and Deaton have documented on the "sea of despair" among white working classes.

\section{Tyranny of Money}

Clearly, something has gone fundamentally wrong with American society. Many Americans are also beginning to sense that the system isn't working for them. Marvin Zonis, a University of Chicago economist has written an article that describes how "the American system is facing a crisis of legitimacy." The level of confidence that American people have in their key institutions has been declining. Confidence in the US presidency has fallen from 52\% in 1975 to $37 \%$ in 2018. Confidence in the US Congress has plummeted more sharply from $42 \%$ in 1973 to $11 \%$ in 2018 . The explanation that Zonis gives for this declining confidence is credible. As he says, "the central factor in the growing lack of trust and confidence in our institutions has been the realization that our American democracy does not function commensurately with the ideals of the founders or the Constitution. Money has become the key to American political life."

The keyword he uses is "money." If money dictates outcomes in politics, it means that a society has become a "plutocracy." After documenting how the amount of money spent in a US presidential election year has gone from USD 3 billion in 2010 to USD 6.5 billion in 2016, Zonis adds that the "contributors of those many billions expect a return on their investments-and they usually get it. Congressional action on gun legislation, sugar subsidies, policies toward Israel, drug pricing, and countless other issues is best explained by the financing of political campaigns and not by the political preferences of ordinary voters, or even of members of Congress."

Please read the above paragraph again, carefully. It says clearly that the decisions of the US Congress are decided by "contributors of billions" and not by the "political preference of ordinary voters." This observation confirms what Gilens and Page documented earlier. In short, there is no doubt that functionally America has become 
a plutocracy. Yet, equally significantly, Zonis does not use the term "plutocracy" once in his article.

\section{In Denial}

There is an old fashioned adage that says: one must call a spade a spade. Similarly, one must call a plutocracy a plutocracy. The reluctance to do so brings out the key problems facing American society. If America refuses to accept that it has functionally become a plutocracy, how can it possibly find a way out of this challenge? Just as no oncologist can cure a patient of cancer if he or she refuses to submit himself or herself to treatment, similarly America cannot be cured of its plutocracy problem if it remains in denial that such a problem exists.

All this means that there are two possible outcomes. The first is a revolution against the establishment in Washington, DC. Paradoxically this may have been what the working classes thought they were doing when they elected Trump in 2016. They wanted to elect someone outside the establishment and one who would shake up the establishment. When Hillary Clinton responded in 2016 by calling Trump's supporters a "basket of deplorables" it showed that she, together with the rest of the Washington establishment did not understand what the broad masses of Americans were trying to convey. Unfortunately, in electing Trump, the working classes voted in a plutocrat. In office, Trump acted like a plutocrat. He cut taxes for the rich again. The conditions for the bottom 50\% didn't improve.

The second possible outcome is the arrival of enlightenment. At some point in time, the top $1 \%$ in America must come to realize that if they are going to protect most of their personal economic gain in America, and not make an effort to improve the conditions of the bottom $50 \%$, they will only damage the very body politicAmerican society - that is enabling them to become so wealthy.

Fortunately, many wealthy Americans are coming to realize this. Ray Dalio is one of them. Dalio runs the largest, most successful hedge fund in the world, which has succeeded through rigorous empirical research. Dalio has now applied this research to understanding poverty and inequality in America. On his LinkedIn page, Dalio spells out the dramatic decline in the living standards of the majority of Americans and points out that "most people in the bottom $60 \%$ are poor" and cites "a recent Federal Reserve study [that showed that] $40 \%$ of all Americans would struggle to raise USD 400 in the event of an emergency." Worse, Dalio notes that "they are increasingly getting stuck being poor [...]. [T]he odds of someone in the bottom quintile moving up to the middle quintile or higher in a 10 -year period [...] declined from about $23 \%$ in 1990 to only $14 \%$ as of $2011 . "$

The data on social deterioration in America is undeniable. It undercuts the claims that America is a society where hard work brings rewards. For most people, the rewards have dried up. The platitude that "virtue is its own reward" turns out to be grimly and limitingly true. 


\section{Five Hard Steps Forward}

Yet, even if the top $1 \%$ in America, which includes Dalio, were to wish that American society return to its condition of the 1950s and 1960s, when the broad mass of American society was also lifted up as America's economy grew, what should they do? Is there a magic button they can press? Is there a simple "silver bullet" solution to America's problem with plutocracy? Sadly, there are no easy solutions. There are only painful solutions. This article will therefore conclude by suggesting what some of them might be. The first step would be for the Supreme Court's Citizens United decision to be reversed. As Martin Wolf said, this court decision started the slippery slope toward plutocracy in America.

The second step would be for America to emulate the example of its fellow democracies in the European Union and impose strict limits on the amount of money that can be spent on elections. Fortunately, the American people also want to limit the influence of money. A Pew Research Institute survey in 2018 found that "an overwhelming majority (77\%) supports limits on the amount of money individuals and organizations can spend on political campaigns and issues. And nearly two-thirds of Americans (65\%) say new laws could be effective in reducing the role of money in politics."

The third step is to change American ideology in a fundamental way. It should go back to the wisdom of its founding fathers. The founding fathers of America were all disciples of great European philosophers of the Enlightenment period (including John Locke and Montesquieu) and emphasized both Freedom and Equality - as did the aforementioned Rawls. Of late, however, American politicians, starting with Ronald Reagan, have emphasized Freedom and not mentioned Equality in the same breath.

The fourth step is to acknowledge that market forces alone cannot create a level playing field for all Americans. Government must step in to redress major social and economic inequalities. Therefore, Americans should openly declare that Reagan was totally wrong when he said, "government is not the solution to our problems; government is the problem." Instead, Americans should accept the wisdom of Nobel Laureate Amartya Sen who said that for societies to progress they need the "invisible hand" of the free market and the "visible hand" of good governance. Americans have not used the "visible hand" in recent decades, especially since the Reagan-Thatcher revolution.

Fifthly, the American government should declare that the main goal of American society is to go from being number 28 on the Social Progress Index toward becoming number one on this index. Hence, instead of trying to become the number one military power (and wasting trillions fighting unnecessary wars), America will spend its trillions improving the living conditions of Americans measured in the Social Progress Index.

The bottom line is that solutions are out there, and they're available. But these solutions will only work if Americans agree on what the problem is. And the problem is, quite simply, plutocracy. 
Open Access This chapter is licensed under the terms of the Creative Commons AttributionNonCommercial-NoDerivatives 4.0 International License (http://creativecommons.org/licenses/bync-nd/4.0/), which permits any noncommercial use, sharing, distribution and reproduction in any medium or format, as long as you give appropriate credit to the original author(s) and the source, provide a link to the Creative Commons license and indicate if you modified the licensed material. You do not have permission under this license to share adapted material derived from this chapter or parts of it.

The images or other third party material in this chapter are included in the chapter's Creative Commons license, unless indicated otherwise in a credit line to the material. If material is not included in the chapter's Creative Commons license and your intended use is not permitted by statutory regulation or exceeds the permitted use, you will need to obtain permission directly from the copyright holder.

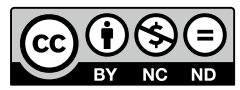

